\title{
The Effect of Using Balanced Scorecard on Competitive Advantage and Its Impact on Firm Performance
}

\author{
Lela Nurlaela Wati \\ lela_nwm@yahoo.com, lela@stiemj.ac.id \\ Economics Study Program \\ STIE Muhammadiyah Jakarta, Jakarta, Indonesia \\ Gunawan Triwiyono \\ gungunawant@gmail.com \\ Economics Study Program \\ STIE Muhammadiyah Jakarta, Jakarta, Indonesia
}

\begin{abstract}
The paper is aimed to examine the effect of balanced scorecard on competitive advantage and its impact to firm performance. The samples of this research are companies that use balanced scorecard in DKI Jakarta as many as 50 companies. This research is uses primary data by giving questionnaires to corporate managers using balanced scorecard. We use Structural Equation Model with SmartPLS. The result of this research shows that there is positive effect between balanced scorecard to competitive advantage. Finding also shows that there is positive effect between balanced scorecard and competitive advantage to firm performance. The research also proves that there is positive effect between balanced scorecard to firm performance through competitive advantage. The findings of this study indicate that the better the application of balanced scorecard in the company will increase the competitive advantage and firm performance.
\end{abstract}

Keywords: balanced scorecard, competitive advantage, firm performance 


\title{
The Effect of Using Balanced Scorecard on Competitive Advantage and Its Impact to Firm Performance
}

\author{
Lela Nurlaela Wati \\ lela_nwm@yahoo.com, lela@stiemj.ac.id \\ Economics Study Program \\ STIE Muhammadiyah Jakarta, Jakarta Selatan, Indonesia \\ Gunawan Triwiyono \\ lela_nwm@yahoo.com, lela@stiemj.ac.id \\ Economics Study Program \\ STIE Muhammadiyah Jakarta, Jakarta Selatan, Indonesia
}

\begin{abstract}
Abstrak
Artikel ini bertujuan untuk meneliti pengaruh balance scorecard terhadap keunggulan kompetitif. Sampel penelitian ini adalah perusahaan-perusahaan yang menggunakan balance scorecard di DKI Jakarta sebanyak 50 perusahaan. Penelitian ini menggunakan data primer dengan cara mengirimkan kuisioner kepada manajer perusahaan yang menggunakan balance scorecard. Peneliti menggunakan Structural Equation Model - SmartPLS. Hasil penelitian ini menunjukkan bahwa ada pengaruh positif antara balance scorecard terhadap keunggulan kompetitif. Temuan lain adalah adanya pengaruh positif antara balance scorecard dan keunggulan kompetitif terhadap kinerja perusahaan. Selain itu, hasil riset juga menyatakan adanya pengaruh positif antara balance scorecard terhadap keunggulan kompetitif terhadap kinerja perusahaan melalui keunggulan kompetitif. Temuan penelitian ini menunjukkan penerapan balance scorecard di perusahaan akan meningkatkan keunggulan kompetitif dan kinerja perusahaan.
\end{abstract}

Kata Kunci: balanced scorecard, keunggulan kompetitif, kinerja perusahaan 


\section{INTRODUCTION}

In the globalization era, competition increasing tight in various business fields, especially in big cities. The firm performance has always been a measure of the company's success so that requires a method that can measure the performance (Kaplan \& Norton, 1996). The importance of measuring performance appropriately, according to Keats \& Hitt (1988) because performance is a difficult concept, both the definition and measurement. By knowing the performance condition then the company can make revisions to the policies that are not relevant so that future achievement will be better.

In assessing of the firm performance, generally many companies still use the financial statements as the only benchmark of business performance. Performance appraisal from a financial perspective only can cause weaknesses, because a good financial performance can be achieved by sacrificing the company's long-term interests. The weaknesses are (1) not paying attention to the investment risk associated with the cost of capital, (2) not describing the value creation for the company and (3) short term oriented (Utama, 1997), so the use of financial ratios in the financial statements is abandoned. Due to the limitations of existing performance appraisals so Kaplan and Norton (1996) formulates new method that can measure performance comprehensively, namely the Balanced Scorecard (BSC). Performance measurement by Balanced Scorecard uses several integrated perspectives, namely financial perspective, customer perspective, business process perspective and growth and learning perspective

The creation of good corporate performance cannot be separated from the competitive advantage owned by the company. The company's ability to create competitive advantage will strengthen the company's position in long-term business competition. In achieving competitive advantage itself, there are five dimensions that are used to assess how good a company's competitive advantage is. The five dimensions of competitive advantage are price, quality, dependable delivery, production innovation and time to market (Li et al.,, 2006).

One of the keys to successful implementation of Balanced Scorecard is the full support of every layer of management that exists within the organization. An opinion under the Balanced Scorecard can help a company to manage changes, as well as helping managers to develop all modes of evaluation that affect company value (Bermser, 1999; Norreklit, 2003; Davis \& Albright, 2004).

Firm performance refers to how well an organization achieves goals with market oriented as well as financial goals (Yamin et al.,, 1999). A number of previous studies have measured firm performance using financial criteria and market criteria, (Vickery, et al.,, 1999, Wati, et. al., 2016). However, according to Neely (1999) firm performance can be measured by financial and non-financial indicators. Venkatraman \& Ramanujam (1986) said that the firm performance has three dimensions of financial performance, operational performance and stakeholder performance. By paying attention to the measurement of the firm performance, it can encourage efforts to realize the goals, objectives, mission and vision of the organization that aims to create maximum performance for the company.

Several previous studies have supported that the use of Balanced Scorecard within the company has a positive effect on competitive advantage. The competitive advantage improvement of a company will have an impact on improving the firm performance and the use of Balanced Scorecard within the company gives a positive impact on the improvement of firm performance (Sim \& Koh, 2001; Kallas, 2006; Li et al., 2006; Strohhecker, 2007: Tuan \& Yoshi, 2010; Der \& Hsu, 2011; Tewal, 2012; Prayhoego, 2013; Lokatili et al., 2013). Based on the above background, it can be formulated problem as follows: 
1. Does the use of Balanced Scorecard affect company's competitive advantage?

2. Does the use of Balanced Scorecard affect firm performance?

3. Does the company's competitive advantage affect irm performance?

4. Does Balanced Scorecard affect firm performance through competitive advantage?

\section{LITERATURE REVIEW}

\section{Balanced Scorecard}

The Balanced Scorecard is an approach to management strategies developed by Robert Kaplan and Norton in the early 1990s. The Balanced Scorecard comes from two balanced and scorecard words. Balanced means a balance between financial and non-financial performance, short-term performance and long-term performance, between internal performance and external performance. While the scorecard is a card used to record a person's performance score. The scorecard can also be used to plan the scores that want to be realized by person in the future.

In its application, according to Kaplan and Norton (2006), Balanced Scorecard is measured using four perspectives: financial perspective, customer perspective, internal business perspective, and learning and growth perspective. While managing and improving business processes, customers and employee satisfaction, the financial perspective should also be enhanced due to this perspective is a measure of the end result of organizational assessment (Bhasin, 2008) because financial performance measures provide clues whether the company's strategy, and its implementation give contribution or not to increase company's profit. The importance of customer focus and customer satisfaction is quite important in the new management philosophy (Ahmadi et.al., 2012). Recent management research has shown an increasing awareness of the importance of customer focus and customer satisfaction in any business (Qin et.al., 2013).

In the internal business process perspective that is determining the process that satisfies the company's shareholders and customers (Kaplan \& Norton, 2001). The internal business perspective focuses on whether an organization should perform customer needs well, defined in the customer perspective (Ahmadi et.al., 2012). The learning and growth perspective has measurement indicators related to the creation of long-term growth and organizational improvement through workforce/employees, system and organizing programs (Kaplan \& Norton, 1996).

Another thing that is gained by applying the Balanced Scorecard method is the retention of workers, which is the ability to retain the best employees or employees in the company. Because with this method employee performance can be measured and assessed in futures. As we have often heard that human resource is a long-term investment company. Employee retention is measured by turnover percentage. Work productivity is also seen by looking at the results of the overall impact of skills and moral enhancement, innovation, internal processes and customer satisfaction. The purpose of it all is to connect the output produced by the worker to the number of workers who are supposed to produce the output.

\section{Competitive Advantage}

Competitive advantage is defined as the ability of an organization to create a position to withstand its competitors and comprises an organizational capability that allows an organization to differentiate itself from its competitors and is a critical outcome of management decisions (Tracey et.al., 1999; Li et.al., 2006).

Competition is critical to a company's success or failure. Competitive strategy is an 
attempt to find a favorable position in an industry, which is a fundamental area in the process of competition. According to Porter (2005), competitive advantage is about how a company actually implements generic strategies into practice.

Companies are said to be able to have sustainable competitive advantage when it can apply value to create strategies that are different from current competitors or potential competitors and when other companies cannot duplicate the benefits of this strategy (Barney, 1991).

\section{Firm Performance}

Firm performance is a description of the financial condition of a company that is analysed with the tools of financial analysis, so it can be known about either the poor financial condition of a company that reflects the performance of work within a certain period. It is very important that resources can be used optimally to face environmental changes. Assessment of financial performance is one way that can be done by the management in order to fulfil its obligations to the funders and also to achieve the goals set by the company. Performance is a term generally used for part or all of the actions or activities of an organization for a period with reference to standard amounts such as historical costs or projected cost, on the basis of efficiency, accountability of management and the like (Srimindarti, 2004). Whereas according to Mulyadi (2007) Performance is the success of personnel, team, or organizational unit in realizing the predetermined strategic goals with the expected behavior.

Firm performance is all the activities undertaken by the company related to the achievement of strategic management goals during a certain period. Performance measurement is also used to assess the achievement of goals and objectives (Whittaker, 1993).

There are several factors that affect performance. According to Amstrong (1998) these factors are as follows:

1. Personal factors. Personal factors are related to skill, motivation, commitment, etc.

2. Leadership factors. Leadership factors are related to the quality of support and direction given by leaders, managers, or group work leaders.

3. Group factors/co-workers (team factors). Group factors/co-workers are related to the quality of support provided by co-workers.

4. System factors. System factors are related to existing systems/methods of work and facilities provided by the organization.

5. Contextual/Situational factors). Situational factors are related to pressure and environmental changes, both internal and external environments.

A performance measurement system is a mechanism that improves the likelihood for a company to have a successful strategy (Anthony and Govindarajan, 2003). Venkatraman and Ramanujam (1986) argue that firm performance has three dimensions, that are financial performance, operational performance and stakeholder performance. However, according to Combs et.al (2005) and Higgins (1995), the most common types of organizational performance measurements often used in empirical research are:

1. Financial and Accounting Performance

2. Operational Performance

3. Performance Based Market

\section{Hypothesis}

Chan (2004) examines the performance of municipal governments in Canada and the 
United States. The study categorized city governments into three categories: (1) not knowing BSC, (2) knowing BSC but not implementing it and (3) implementing BSC. These three categories give different results on the BSC perspective, in which city governments implementing BSC have better performance.

Kallas (2006) examined the implementation of Balanced Scorecard in management strategy which resulted the finding that Balanced Scorecard positively affect to competitive advantage.

Sim and Koh (2001), compared traditional performance measurement systems based on financial indicators with the Balanced Scorecard and the effect of both systems on firm performance. The results showed that there is a positive effect Balanced Scorecard and performance measurement system associated with strategies and objectives in improving firm performance.

Strohhecker (2007) examined the effect of Balanced Scorecard on firm performance. The results of this study indicate that the use of Balanced Scorecard gives a positive effect on firm performance.

Tuan and Yoshi (2010), examined the organization's capabilities, competitive advantage and organizational performance in boosting companies in Vietnam. The results of Tuan and Yoshi's research showed that competitive advantage had a positive and significant effect on firm performance.

Li et.al. (2006), examined the effect of supply chain management on competitive advantage and firm performance. One of the findings is that there is a positive effect of competitive advantage on firm performance.

Prayhoego (2013), examines the effect of Total Quality Management on competitive advantage and firm performance. In this research, it was found that there is significant effect between competitive advantage to firm performance.

Lokatili et al., (2013) conducted a research on the effect of Balanced Scorecard on competitive advantage and firm performance in Indonesia, the results showed that Balanced Scorecard positively effect to competitive advantage and firm performance, as well as competitive advantage positively effect to firm performance, but they didn't analyze indirect effect of Balanced Scorecard on firm performance through competitive advantage. So, our research aim to fill the gaps in the literature to exemine direct and indirect effect of Balanced Scorecard to firm performance throught competitive advantage. The following figure is a research framework. 


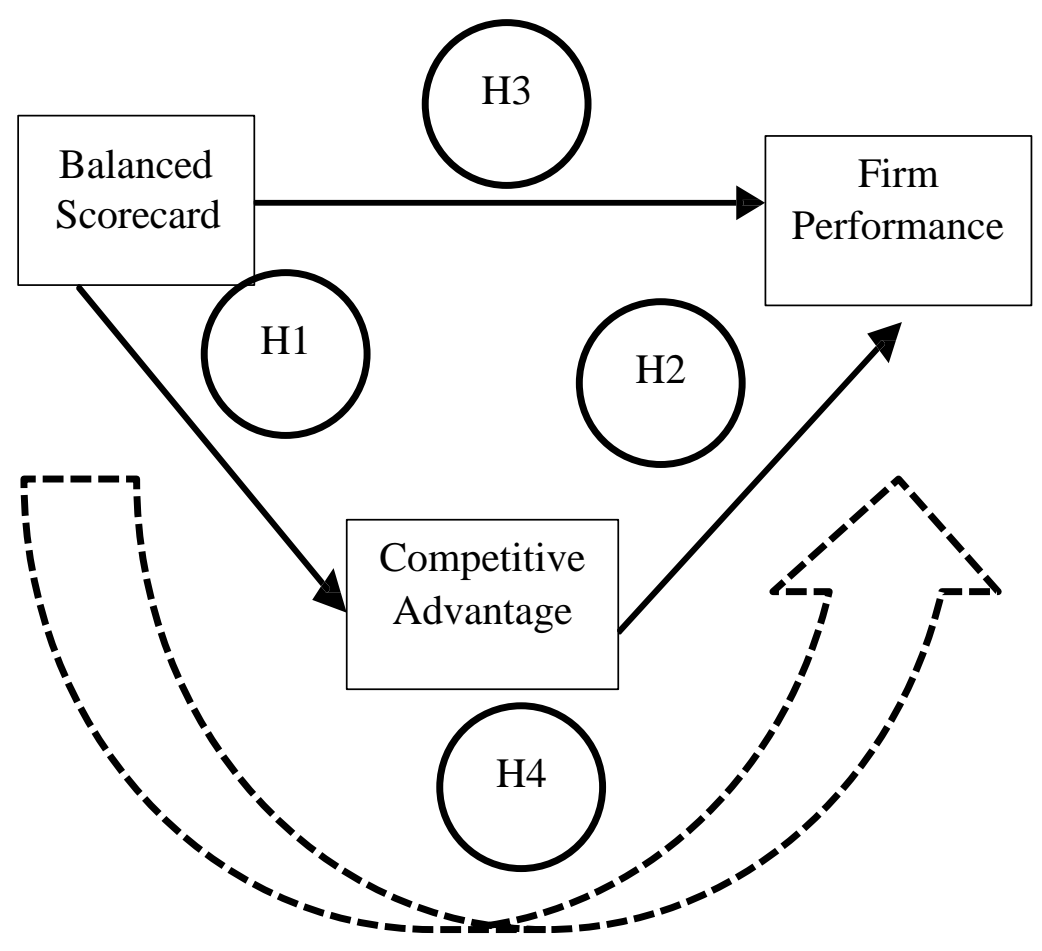

Source: Literature Review

Figure 1: Research Framework

Based on the results of previous research and to fill the gap of previous research on indirect effect, the authors formulate the following hypothesis:

$\mathrm{H} 1=$ The use of balanced scorecard has a positive effect on competitive advantage.

$\mathrm{H} 2=$ The use of balanced scorecard has a positive effect on firm performance

H3 = Competitive advantage positively affects on firm performance.

$\mathrm{H} 4=$ The use of balanced scorecard has a positive effect on firm performance through competitive advantage.

\section{RESEARCH METHOD}

The sample in this research are companies that use Balanced Scorecard in DKI Jakarta area as many as 50 companies. This study uses primary data by giving questionnaires to corporate managers which using Balanced Scorecard in DKI Jakarta area. Data analysis uses Structural Equation Model with SmartPLS.

The variables used in this research are Balanced Scorecard as independent variable, competitive advantage as intervening variable, and firm performance as dependent variable

The following table 1 explains the operationalization of variables: 
Table 1. Description of Variables

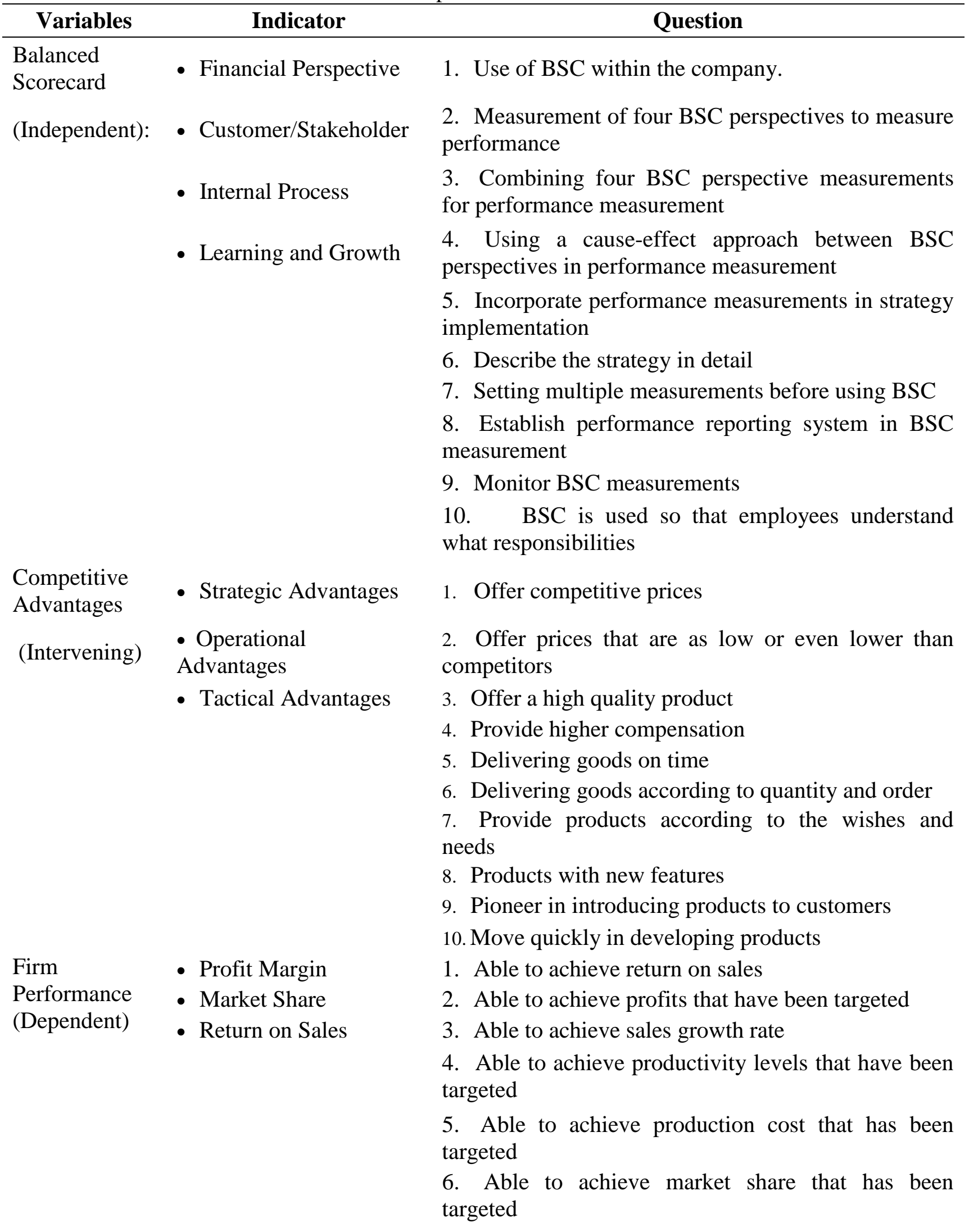


7. Always introduce new products

8. Able to offer products / services accordingly

9. Able to cover the entire scope of market share

10. Able to meet customer needs

Source: Literature

To test the research hypothesis, the model used is as follows:

$$
\begin{aligned}
& C A=\alpha+\beta_{1} B S C+e_{1} \\
& F P=\alpha+\beta_{2} B S C+\beta_{3} C A+\beta_{4} B S C C A+e_{2}
\end{aligned}
$$

To detect the effect of mediation, it can be done by a procedure developed by Hair et. al. (2011). The conditions in this test are: First, the direct effect must be significant when the mediating variable has not been incorporated into the model. Second, after the mediating variable is incorporated into the model, the indirect effect must be significant. Each path must be significant to satisfy this condition. Third, calculate variance accounted for (VAF) with the formula of indirect effect / total effect. VAF is a measure of how much the mediating variable is able to absorb the previously significant direct effect of the model without mediation. If the VAF value above $80 \%$ indicates the role of the mediating variable as full mediation. If the VAF is worth between $20 \%-80 \%$ then it can be categorized as a partial mediator. However, if the VAF is less than $20 \%$, the researcher can conclude that there is virtually no mediation effect (Hair et. al., 2011).

\section{RESULTS AND DISCUSSION}

\section{Descriptive Analysis}

The following table describes the industrial sector of the firms from respondents in this study:

Table 2. Industrial Sector

\begin{tabular}{lcc}
\hline $\begin{array}{c}\text { Industrial } \\
\text { Sector }\end{array}$ & Frequency & $\begin{array}{c}\text { Percentage } \\
(\boldsymbol{\%})\end{array}$ \\
\hline Manufacture & 8 & 16 \\
Services & 23 & 46 \\
Retail & 5 & 10 \\
Finance & 8 & 16 \\
Others & 6 & 12 \\
Total & $\mathbf{5 0}$ & $\mathbf{1 0 0}$ \\
\hline
\end{tabular}

Source: Data processed

Based on the Table 2 above, it is known that from total of 50 respondents who become the object of research is the industrial sector of the company It can also be seen from the total of 50 companies there are $16 \%$ percentage for manufacturing sector, $46 \%$ for service industry, $10 \%$ for retail industry, $16 \%$ for financial industry sector and $12 \%$ for other industrial sectors.

The following is descriptive of work length of managers who became respondents in this study: 
Table 3. Work Length of Respondent

\begin{tabular}{lcc}
\hline \multicolumn{1}{c}{ Work Length } & Frequency & Percentage \\
\hline 1-4 years & 28 & 56 \\
5 - 8 years & 20 & 40 \\
$>9$ years & 2 & 4 \\
Total & $\mathbf{5 0}$ & $\mathbf{1 0 0}$
\end{tabular}

Source: Data processed

Based on Table 3, it is known that the length of work of the respondents is $1-4$ years $56 \%, 5-8$ years $40 \%$ and for $>9$ years by $4 \%$. It can be concluded that the respondents in this study are managers who have been working for more than 1 year.

Below is the descriptive gender of the manager who became the respondent in this study.

Table 4. Gender of Respondents

\begin{tabular}{lcc}
\hline Gender & Frequency & $\begin{array}{c}\text { Percentage } \\
(\mathbf{\%})\end{array}$ \\
\hline Male & 32 & 64 \\
Female & 18 & 36 \\
Total & $\mathbf{5 0}$ & $\mathbf{1 0 0}$ \\
\hline \multicolumn{2}{l}{ Source: Data processed }
\end{tabular}

Based on the table above, it can be seen that the number of male and female respondents are as much as $64 \%$ and $36 \%$

\section{Descriptive of Respondents Answers}

In this analysis the respondents' answers will be explained on each research variable, namely Balanced Scorecard, competitive advantage and firm performance. Description of the respondent's answer is done by calculating the mean value of the respondent's answer to each question and overall. Class interval is used to categorize the average respondent answers related Balanced Scorcard, competitive advantages and firm performance:

Table 5. The Average Category of Respondents' Answers

\begin{tabular}{ccc}
\hline Interval & Category & Indication \\
\hline $4.20<\mathrm{a} \leq 5.00$ & Strongly agree & Very good \\
$3.40<\mathrm{a} \leq 4.20$ & agree & Good \\
$2.60<\mathrm{a} \leq 3.40$ & Neutral & Enough \\
$1.80<\mathrm{a} \leq 2.60$ & Not agree & Not good \\
$1.00<\mathrm{a} \leq 1.80$ & Strongly not agree & $\begin{array}{c}\text { Very not } \\
\text { good }\end{array}$ \\
\hline
\end{tabular}

Source: Data processed 


\section{Hypothesis Test}

\section{Outer Model}

The relationship between variables and indicators can be seen from the measurement model (outermodel). Outer model evaluation is done to know the validation and reliability of data. Validation includes convergent validity and discriminant validity, and reliability is sought through composite reliability.

\section{Convergent Validity}

The indicator is stated met the convergent validity if it has a loading value above 0.5. Here are the results of convergent validity for Balanced Scorecard variables, competitive advantages and firm ferformance in companies which implementing Balanced Scorcard in Jakarta.

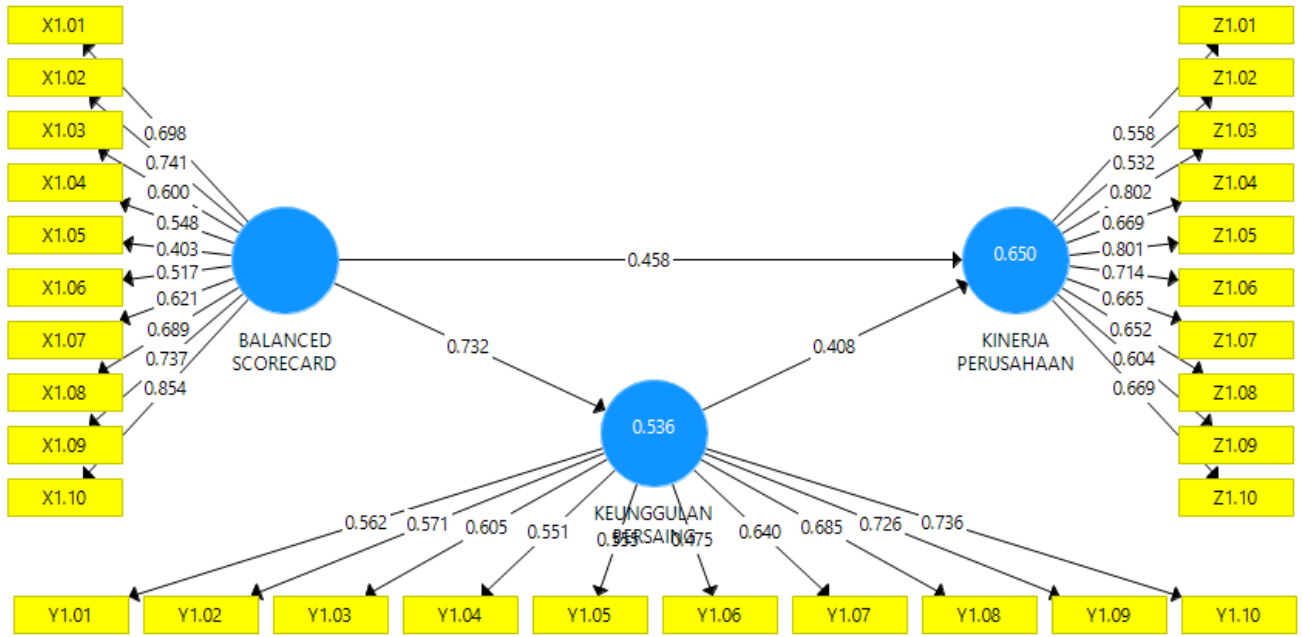

Source: Data processed

Figure 2: Outermodel Before Dropping the Indicators 
Table 6. Value of the Beginning Outer Loading

\begin{tabular}{cccccc}
\hline \multicolumn{2}{c}{ Balanced Scorecard } & \multicolumn{2}{c}{ Competitive Advantage } & \multicolumn{2}{l}{ Firm Performance } \\
\hline X1 & 0,698 & Y1 & 0,562 & $\mathrm{Z} 1$ & 0,558 \\
X2 & 0,741 & Y2 & 0,571 & $\mathrm{Z} 2$ & 0,532 \\
X3 & 0,600 & Y3 & 0,605 & $\mathrm{Z} 3$ & 0,802 \\
X4 & 0,548 & Y4 & 0,551 & $\mathrm{Z} 4$ & 0,669 \\
X5 & 0,403 & Y5 & 0,555 & $\mathrm{Z} 5$ & 0,801 \\
X6 & 0,517 & Y6 & 0,475 & $\mathrm{Z} 6$ & 0,714 \\
X7 & 0,621 & Y7 & 0,640 & $\mathrm{Z} 7$ & 0,665 \\
X8 & 0,689 & Y8 & 0,685 & $\mathrm{Z} 8$ & 0,652 \\
X9 & 0,737 & Y9 & 0,726 & $\mathrm{Z} 9$ & 0,604 \\
X10 & 0,854 & Y10 & 0,736 & $\mathrm{Z} 10$ & 0,669 \\
\hline
\end{tabular}

Source: Data processed SmartPLS (2017)

Based on Figure 2 and Table 6 above, the value of outer loading indicator variable Balanced Scorecard of X1 - X10, there is still outer loading value under 0.5 that is X5 and Y6. The outer loading is still to be fixed by removing the indicators whose value still below 0.5 , which are $\mathrm{X} 5$ and $\mathrm{Y} 6$

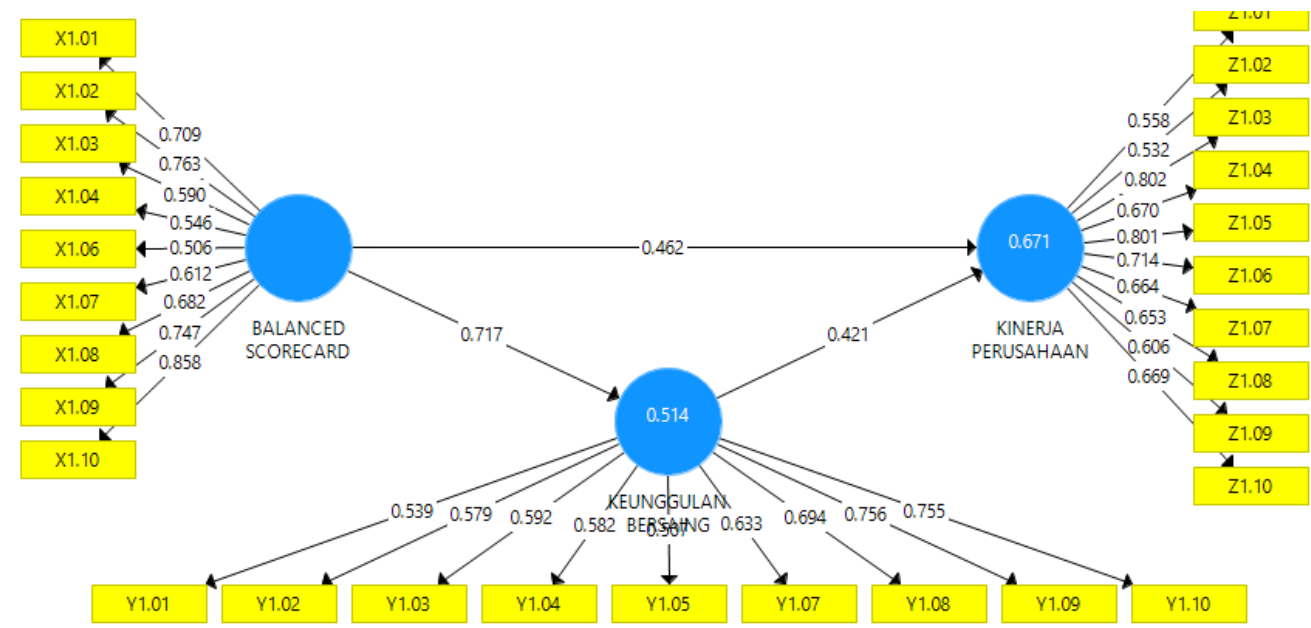

Source: SmartPLS Result

Figure 3. Outermodel After Dropping the Variables 
Table 7. Value of Final Outer Loading

\begin{tabular}{cccccc}
\hline \multicolumn{2}{c}{$\begin{array}{c}\text { Balanced } \\
\text { Scorecard }\end{array}$} & \multicolumn{2}{c}{$\begin{array}{c}\text { Competitive } \\
\text { Advantage }\end{array}$} & \multicolumn{2}{c}{$\begin{array}{c}\text { Firm } \\
\text { Performance }\end{array}$} \\
\hline $\mathrm{X} 1$ & 0,709 & $\mathrm{Y} 1$ & 0,539 & $\mathrm{Z} 1$ & 0,558 \\
$\mathrm{X} 2$ & 0,763 & $\mathrm{Y} 2$ & 0,579 & $\mathrm{Z} 2$ & 0,532 \\
$\mathrm{X} 3$ & 0,590 & $\mathrm{Y} 3$ & 0,592 & $\mathrm{Z} 3$ & 0,802 \\
$\mathrm{X} 4$ & 0,546 & $\mathrm{Y} 4$ & 0,582 & $\mathrm{Z} 4$ & 0,670 \\
$\mathrm{X} 6$ & 0,506 & $\mathrm{Y} 5$ & 0,507 & $\mathrm{Z} 5$ & 0,801 \\
$\mathrm{X} 7$ & 0,612 & $\mathrm{Y} 7$ & 0,633 & $\mathrm{Z} 6$ & 0,714 \\
$\mathrm{X} 8$ & 0,682 & $\mathrm{Y} 8$ & 0,694 & $\mathrm{Z} 7$ & 0,664 \\
X9 & 0,747 & $\mathrm{Y} 9$ & 0,756 & $\mathrm{Z} 8$ & 0,653 \\
$\mathrm{X} 10$ & 0,858 & $\mathrm{Y} 10$ & 0,755 & $\mathrm{Z} 9$ & 0,606 \\
& & & & $\mathrm{Z} 10$ & 0,669 \\
\hline
\end{tabular}

Source: Data processed SmartPLS (2017)

Based on Figure 3 and Table 7 above, the value of outer loading indicator variable Balanced Scorecard, competitive advantage and firm performance already had value above 0.5 , in other words the indicators have been good to measure the variables that being measured so it can meet the convergent validity, so there is no need for other indicators to be eliminated.

\section{Composite Reliability}

This test is performed to test the reliability value between the indicators block of the construct that form it. Here is the output of composite reliability.

Table 8. Composite Reliability

\begin{tabular}{lc}
\hline \multicolumn{1}{c}{ Construct } & Composite Reliability \\
\hline Balanced Scorecard & 0,881 \\
Competitive & 0,855 \\
Advantage & 0,890 \\
Firm Performance & \\
\hline
\end{tabular}

Source: Data processed SmartPLS (2017)

Composite reability is good which has a value above 0.70 . Based on the results of the above table, it can be seen that the value of composite reliability for the Balanced Scorecard variable is 0.881 , while the competitive advantage variable is 0.855 , and the firm performance variable is 0.890 where all values are all greater than 0.70 . Thus it can be said that the model in this study has met the composite reliability. 


\section{Inner Model}

Based on data processing with Smart PLS, so the coefficient of determination (R-square) as follows:

Table 9. Value of R-Square Model

\begin{tabular}{lc}
\hline \multicolumn{2}{c}{ R-Square } \\
\hline Competitive & 0,514 \\
Advantage & 0,671 \\
$\mathrm{Q}^{2}$ & 0,84 \\
\hline \multicolumn{2}{l}{ Source: Data processed SmartPLS (2017) }
\end{tabular}

Goodness of fit on smart PLS is known from the value of $\mathrm{Q}^{2}$. The value of $\mathrm{Q}^{2}$ has the same meaning as the coefficient of determination ( $R$-square $/ \mathrm{R}^{2}$ ) in the regression analysis. The higher $\mathrm{R}^{2}$ value the better model with data.

From the data in Table 8 above can be seen the value of $\mathrm{Q}^{2}$ as follows:

$$
\begin{aligned}
& \mathrm{Q}^{2}=1-[(1-0,514)(1-0,671)] \\
& \mathrm{Q}^{2}=1-(0.486)(0.329) \\
& \mathrm{Q}^{2}=1-0.159894 \\
& \mathrm{Q}^{2}=0.840=84.0 \%
\end{aligned}
$$

In this study, the R-square value obtained in equation of competitive advantage is 0,514 , which means the effect of Balanced Scorecard to competitive advantage is $51.4 \%$. While the value of $\mathrm{R}$-square generated at the firm performance equation is 0.671 , which means the effect of Balanced Scorecard on firm performance is equal to $67.1 \%$.

From this research model is known that value of $\mathrm{Q}^{2}$ equal to $84,0 \%$. It can be interpreted the model used in this study can explain the information contained in the data of $84 \%$.

\section{Significance Test}

To see the significance of Balanced Scorecard, competitive advantage and firm performance can be done by looking at the value of parameter coefficient and significance value of T-statiscisc. The output results can be seen in the following table obtained from the results of smartPLS output using calculate-PLS Bootstrapping.

Table 10. Path Coefficients

\begin{tabular}{lccccc}
\hline \multicolumn{1}{c}{ Hypothesis } & Prediction & Coeficient & t Statistics & P Values & Result \\
\hline BSC -> CA & + & 0.717 & 13.414 & 0 & Supported*** \\
BSC -> FP & + & 0.462 & 3.028 & 0.001 & Supported*** \\
CA -> FP & + & 0.421 & 2.769 & 0.003 & Supported*** \\
BSC ->CA ->FP & + & 0.302 & 2.649 & 0.004 & Supported*** \\
\hline Notes $* * * \operatorname{sig}$ level 1\% $* * \operatorname{sig}$ 5\% $*$ sig $10 \%$ & & &
\end{tabular}

Notes: ***sig level 1\%, **sig 5\%, * sig 10\%

Source: Data processed SmartPLS (2017) 


$$
\begin{aligned}
& C A=\alpha+0.717 B S C+e_{1} \\
& F P=\alpha+0.462 B S C+0.421 C A+0.302 B S C C A+e_{2}
\end{aligned}
$$

Based on the above table, Balanced Scorecrd has a positive effect on firm performance and significant at $1 \%$ level. The results of this study in accordance with the results of previous studies done by Sim \& Koh (2001), Strohhecker(2007), Der \& Hsu (2011), Lokatili et.al., (2013), where they produce the same findings, namely the use of Balanced Scorecard positively affect the firm performance. These results indicate that the use of Balanced Scorecard is effectively used by companies in Jakarta, not only in manufacturing companies, but also in other sectors. This result is supported by the second hypothesis, where the Balanced Scorecard has a positive effect on the competitive advantage. This agrees with the findings of Kallas (2006), Lokatili et al., (2013). This result indicates that the existence of a Balanced Scorecard on a company can increase the competitive advantage of the company.

Competitive Aavantages also positively affect on firm performance on the companies that use Balanced Scorecard in Jakarta. The results of this study support the results of previous research conducted by Tuan \& Yoshi (2010), Tewal (2012), Li et. al. (2006), Prayhoego (2013), Lokatili at et. al., (2013) where competitive advantage has a significant positive effect on firm performance. These results indicate that the existence of competitive advantage in companies that use Balanced Scorecard will give a positive effect on firm performance.

There is a positive effect between Balanced Scorecard on firm performance through competitive advantage on companies that use Balanced Scorecard in Jakarta. This result means that the existence of Balanced Scorecard will give positive effect to firm performance through competitive advantage to company.

Based on calculation of VAF from Table 10 above $(0,302 / 0,302+0,462)$, obtained value equal to 0,3953, which means indirect effect of Balanced Scorecard to firm performance is $39,53 \%$ which mean there is partial mediation effect of Balanced Scorecard to company performance through competitive advantages and significant.

From the results of data processing can be seen that the main factor causing corporate performance in companies that use Balanced Scorecard in Jakarta is how big the contribution of the company's managers in using and applying Balanced Scorecard in the company properly and correctly. This can be seen from the results of research stating that the Balanced Scorecard can directly improve the firm performance in operational performance indicators supported by indicators of Balanced Scorecard criteria.

\section{CONCLUSION}

Based on research result, it can be concluded that there is positive and significant effect between Balanced Scorcard to competitive advantage and firm performance partially. There is positive effect of competitive advantage and firm performance, and Balanced Scorecard positively effect to firm performance through competitive advantage.

The use of Balanced Scorecard helps managers within the company to translate the company's vision, mission and objectives, so that managers can achieve the firm performance and suitable competitive advantage for the company. The use of Balanced Scorecard can also help managers in knowing the weaknesses of the company, so that it can quickly improve the weaknesses and firm performance which company expected can be achieved in accordance with corporate objectives. 


\section{REFERENCES}

Ahmadi, P., Khoddami, S., Osanlou, B., \& Moradi, H. (2012). Using the Balanced Scorecard to design organizational comprehensive performance evaluation model. African Journal of Business Management, 6(6), 2267-2277.

Amstrong, M. (1998). Performance Management. Clays, Ltd. St. Ives Ple, England.

Anthony, R.N., \& Govindarajan, V. (2003). Management Control System $11^{\text {th }}$ Edition. Boston: Mcgraw Hill

Barney, J. B. (1991). Firm Resources \& Sustained Competitive Advantage. Journal of Management, 17, 99-120.

Bhasin, S. (2008). Lean and Performance Measurement. Journal of Manufacturing Technology.

Carton, R. B. (2004). Measuring Organizational Performance: An Exploratory Study, Edward Elgar Publishing Limited.

Combs, J. G. T., Crook, R., \& Christopher, L. S. (2005). The Dimensionality of Organizational Performance and its Implications for Strategic Management Research. In Professor David Ketchen and Professor Don Bergh (Ed.) Research Methodology in Strategy and Management, 2, 259-286.

Davis, S. \& Albright, T. (2004). An Investigation of the Effect of Balances Scorecard Implementation on Financial Performance. Management Accounting Research, 15(2), 135-153.

Der Jang, Chi \& Hsu Feng, Hung (2011). Is the Balanced Scorecard Really Helpful for Improving Performance? Evidence from Software Companies in China and Taiwan. African Journal of Business Management, 5(1), 224-239.

Hair, Black, Babin, Anderson \& Tatbam. (2011). Multivariate Data Analysis. USA: Pearson International Edition.

Higgins, R. C. (1995). Analysis for Financial Management (4th Edition), Boston, Ma: Irwin.

Kallas, D. (2006). Balanced Scorecard Implementation for Strategy Management: Variation of Manager Opinion in Real and Simulated Companies. Developments in Business Simulation and Experiential Learning, 33, 197-203.

Kaplan, R. S. \& Norton, D. P. (1996). Using the Balanced Scorecard as a Strategic Management System. Harvard Business Review, 74(1), 75-85.

Kaplan, R. S., \& Norton, D. P. (2001). The Strategy-Focused Organization: How BSC Companies Thrive in the New Competitive Environment.

Kaplan, R. S., \& Norton, D. P. (2006). How to Implement a New Strategy without Distruping Your Organization. Harvard Business Review, 84(3), 100.

Keats, B.W. \& Hitt, M.A (1988) "A Causal Model of Linkages Among Environmental Dimension, Macro Organizational Characteristics and Performance", Academy of Management Journal, 31(3), 570-598.

Li, S., Ragu-Nathan, B., Ragu-Nathan T. S., \& Rao, S. S. (2006). The Impact of Supply Chain Management Practices on Competitive Advantage and Organizational Performance. Omega, 34, 107-124.

Lokatili, Tifany Armin, and Devie. (2013). "Analysis of the Effect of Balanced Scorecard on Competitive Advantage and Company Performance". Business Accounting Review, 1.2: $72-81$.

Mulyadi. (2007). Management Accounting: Concepts, Benefits, and Engineering, Edition 3. Jakarta: Salemba Empat.

Neely, A.D. (1999). "The Performance Measurement Revolution: Why Now and Where Next", International Journal of Operations and Production Management, 19(2), 205228 . 
Norreklit, H. (2003). The Balances Scorecard: What is the Score? A Theoretical Analysis of the Balanced Scorecard. Account. Org. Soc., 28(6), 591-619.

Porter, M. E. (2005). Competitive Strategy New York: The Dryden Press A Division of Macmillan Publishing Co. Inc.

Prayhoego, Callystha Adhelline. (2013). "Influence Analysis of Total Quality Management on Competitive Advantage and Company Performance". Business Accounting Review, 1.2: 236-245.

Qin, S. Y., Atkins, A. S., \& Yu, H. (2013). Balanced Scorecard Approach to Evaluate Business Performance Measurement Using Web Tools in E-Tourism. International Journal of Computing Science and Communication Technologies, 5(2).

Sim, K. L., \& Koh, H. C. (2001). Balanced Scorecard: A Rising Trend in Strategic Performance, Measurement. Measuring Business Excellence, 5(2).

Srimindarti, Ceacilia. (2004). Balanced Scorecard as an Alternative to Measure Performance. Fokus Ekonomi, 3(1).

Strohhecker, J. (2007). Does a Balanced Scorecard Management Cockpit Increase Strategy Implementation Performance?, System Dynamics Society Conference.

Tuan, N. P., \& Yoshi, T. (2010). Organisational Capabilities, Competitive Advantage and Performance in Supporting Industries in Vietnam. Asian Academy of Management Journal, 15(1), 1-21.

Tracey, M., Vonderembse, M. A., \& Lim J. S. (1999). Manufacturing Technology and Strategy Formulation: Keys to Enhancing Competitiveness and Improving Performance. Journal of Operations Management, 17(4), 411-428.

Utama, Sidharta (1997), "Economic Value Added: Measurement of Value Creation", Manajemen Usaha Indonesia, No. 4, Th.XXVI

Venkatraman, N., \& Ramanujam, V. (1986). Measurement of Business Performance in Strategy Research: A Comparison of Approaches. Academy of Management Review, 11(4), 801-814.

Vickery, S., Calantone, R., \& Droge, C. (1999). Supply Chain Flexibility: An Empirical Study. Journal of Supply Chain Management, 35(3), 16-24.

Wati, L. N., Primiana, I., \& Sudarsono, R. (2016). Political Connections of Conglomerates: Evidence Form Indonesia Stock Exchange. Actual Problems in Economics, (186), 110119.

Whittaker, James B. 1995. The Government Performance and Result Act of 1993: A Mandate for Strategic Planning and Performance Measurement, Educational Services Institut: Arlington, Virginia.

Yamin S, Gunasekaran A, Mavondo F.T. (1999). Relationship between Generic Strategies, Competitive Advantage and Organizational Performance: An Empirical Analysis. Technovation, 19(8), 507-518. 